\title{
Effects of light on pigments and photosynthetic activity in a phycoerythrin-rich strain of Spirulina subsalsa
}

\author{
L. Tomaselli, M. C. Margheri, A. Sacchi \\ Centro di Studio dei Microrganismi Autotrofi del CNR, P. le delle Cascine, I-27-50144 Firenze, Italy
}

\begin{abstract}
Data on acclimation to 2 photon flux densities (15 and $100 \mu \mathrm{mol}$ photons $\mathrm{m}^{-2} \mathrm{~s}^{-1}$ ) in Spirulina subsalsa strain $3 \mathrm{~F}$, a highly fluorescent phycoerythrin-rich cyanobacterium isolated from the brackish Lake Faro (Messina, Italy), indicated plasticity of the photosynthetic apparatus of this organIsm. High-irradiance grown cells showed the greatest photosynthetıc capacity even though they had a lower chlorophyll and phycobiliprotein content. Carotenoids decreased to a lesser extent but their composition changed. $\beta$-carotene decreased, while the amount of myxoxanthophyll more than doubled. The stability of both C-phycoerythrin and C-phycocyanin ratios in cells grown under different light quality (green and red) demonstrated the lack of complementary chromatic adaptation in S. subsalsa. This factor, combined with the efficient utilization of low-wavelength light, indicates the strong adaptation of this strain to its habitat.
\end{abstract}

KEY WORDS: Pigments · Oxygen evolution - Photoacclimation S Spirulina subsalsa C Cyanobacteria

\section{INTRODUCTION}

Cyanobacteria of the genus Spirulina Turpin are frequently found in thermal springs and in brackish or marine waters, mostly eutrophic, where they can form dense populations, and make major contributions to primary productivity (Anagnostidis \& Golubic 1966, Tomaselli Feroci \& Balloni 1976, Castenholz 1977, Bazzichelli et al. 1978). The common species S. labyrinthiformis Gomont, S. major Kuetzing and S. subsalsa Oersted are characterized by a blue-green pigmentation due to the presence of C-phycocyanin, the main light-harvesting pigment of most cyanobacteria. The present study concerns a strain of Spirulina subsalsa, isolated from the brackish meromictic Lake Faro near Messina (Italy), which shows an unusual red pigmentation, due to phycoerythrin-rich phycobilisomes (Tomaselli et al. 1990). The phycoerythrin in this strain possesses a high degree of autofluorescence which increases with exposure to increases in photosynthetic active radiation (PAR) (Tomaselli et al. 1993).

We have examined the effects of distinct photon flux density (PFD) and spectral quality on growth, pigment composition and photosynthetic activity of this particu- lar strain. Our results, besides contributing to the understanding of photoadaption in S. subsalsa, could provide useful information for the possible exploitation of this strain as a source of natural fluorescent dye in immunofluorescent assays (Strier et al. 1985).

\section{MATERIALS AND METHODS}

Organism and growth conditions. Spirulina subsalsa strain $3 \mathrm{~F}$ was isolated from a water sample collected at a depth of $10 \mathrm{~m}$ in Lake Faro. Stock cultures were maintained under $25 \mu \mathrm{mol}$ photons $\mathrm{m}^{-2} \mathrm{~s}^{-1}$ of continuous PAR, at $26^{\circ} \mathrm{C}$ on MN medium (Rippka et al. 1979). For the experiments on photoacclimation, cells were cultured in a Gallenkamp orbital incubator at $26^{\circ} \mathrm{C}$, in an atmosphere of $\mathrm{CO}_{2}$-enriched air $(5 \%)$. Continuous irradiation of $15 \mu \mathrm{mol}$ photons $\mathrm{m}^{-2} \mathrm{~s}^{-1}$ (LI) and $100 \mu \mathrm{mol}$ photons $\mathrm{m}^{-2} \mathrm{~s}^{-1}$ (HI) was provided by coolwhite fluorescent lamps. Cultures were allowed to acclimate to irradiance levels by diluting them every week with fresh medium. In this way, cells had been acclimated for at least 6 generations before biochemical and physiological determinations were made. Sim- 
ilarly, to determine the effects of spectral quality on cell pigment content, $S$. subsalsa cultures were incubated for a month in white $\left(25 \mu \mathrm{mol}\right.$ photons $\left.\mathrm{m}^{-2} \mathrm{~s}^{-1}\right)$. red $\left(30 \mu \mathrm{mol}\right.$ photons $\left.\mathrm{m}^{-2} \mathrm{~s}^{-1}\right)$ and green light $(28 \mu \mathrm{mol}$ photons $\mathrm{m}^{-2} \mathrm{~s}^{-1}$ ). Chromatic illumination was obtained by interposition of appropriate colored plastic filters between the cultures and the light source $(400 \mathrm{~W}$ incandescent lamp).

Biomass and pigment analyses. Growth was determined by cell dry weight; trichomes were collected by filtration through a membrane filter of $3 \mu \mathrm{m}$ pore size, washed and dried at $70^{\circ} \mathrm{C}$ to constant weight. Protein, carbohydrate and lipid cell contents were determined as previously reported (Tredici et al. 1988). Chlorophyll a (chl a) and phycobiliprotein (PBP) contents were determined spectrophotometrically using the methods of Vonshak et al. (1985), and of Bennet \& Bogorad (1973), respectively. Total carotenoid content was estimated spectrophotometrically as reported by Paoletti (1969). Specific carotenoids were isolated by thin layer chromatography (Kieselgel 60, Merck) and identified spectrophotometrically in different solvents, following Davies (1965).

Photosynthetic activity determination. Rates of photosynthetic oxygen evolution and respiratory oxygen uptake were measured on Spirulina subsalsa cultures, diluted to a final concentration of about $2.5 \mathrm{mg} \mathrm{chl} \mathrm{a}^{-1}$ with fresh medium containing $1 \mathrm{~g} \mathrm{l}^{-1} \mathrm{NaHCO}_{3}$, using a Clark-type $\mathrm{O}_{2}$ electrode, at $26^{\circ} \mathrm{C}$ under PFDs ranging from 25 to $760 \mu \mathrm{mol}$ photons $\mathrm{m}^{-2} \mathrm{~s}^{-1}$ (PAR). Red and green light was obtained as described above.

Statistical analyses. Effects of PFD and spectral quality on pigment content and photosynthetic activity were compared by an analysis of variance (ANOVA). The significance between pairs of variable means was analyzed by a least significant difference (LSD) analysis.

\section{RESULTS}

Laboratory cultures of Spirulina subsalsa strain $3 F$ showed the prevalence of the $C$-phycoerythrin (CPE) over the other photosynthetic pigments. In cultures growing at low irradiance (below $40 \mu \mathrm{mol}$ photons $\mathrm{m}^{-2}$ $\mathrm{s}^{-1}$ ) CPE cell content, which represented about $20 \%$ of total cell protein, was more than 10 times greater than that of chl a. It was also about 4 times greater than the sum of the contents of C-phycocyanin (CPC) plus allophycocyanin (APC). Eight distint carotenoids were revealed by thin layer chromatography, 4 of which were present in significant amounts: $\beta$-carotene, myxoxanthophyll, zeaxanthin and a carotenoid having spectral characteristics and Rf values similar to $\beta$ cryptoxanthin.

\section{Effect of PFDs and spectral quality on pigment content}

Spirulina subsalsa cultures exposed to increased PFD showed a general reduction in pigment cell content. PBPs content decreased more markedly than chl a content (about $70 \%$ and $57 \%$, respectively) (Table 1 ). Therefore, with increasing PFD, there was a reduction in the CPE:chl a and CPC:chl a ratios. Total carotenoid content was reduced with increasing PFD, but to a lesser extent than chl a content, resulting in an increase of the total carotenoids: $\mathrm{chl}$ a ratio. Decreases in the relative abundance of $\beta$-carotene in the carotenoid pigments coincided with increasing PFD, while myxoxanthophyll increased noticeably. Due to the reduction of $\beta$-carotene, zeaxanthin was the prevalent carotenoid at higher irradiance (Fig. 1).

Cell pigment composition of Spirulina subsalsa was altered little by spectral quality (Table 1). The ratio of phycoerythrin contents after growth in red and green light [CPE (red):CPE (green)] and the one of phycocyanin contents under the same conditions [CPC (red) : CPC (green)] did not vary by more than 15\%, indicating a lack of chromatic adaptation in this strain.

\section{Photosynthetic activity of LI and HI cultures}

The curves of photosynthetic activity to increasing PFD of Spirulina subsalsa 3F cultures grown at LI or HI showed that the strain underwent some degree of

Table 1 Effects of photon flux density (PFD) and spectral quality on pigment composition (mg $\mathrm{g}^{-1}$ dry weight) of Spirulina subsalsa strain $3 F$. Data are means \pm standard deviation $(n=4)$. For each experiment, variable means with the same letter are not significantly different ( $p>0.05$ )

\begin{tabular}{|lccrcr|}
\hline Light conditions & Chl a & CPE & CPC & APC & Carotenoids \\
\hline White light $\left(100 \mu \mathrm{mol}\right.$ photons $\left.\mathrm{m}^{-2} \mathrm{~s}^{-1}\right)$ & $4.02 \pm 0.18 \mathrm{a}$ & $29.32 \pm 1.94 \mathrm{a}$ & $6.09 \pm 0.68 \mathrm{a}$ & $0.88 \pm 0.15 \mathrm{a}$ & $0.97 \pm 0.10 \mathrm{a}$ \\
White light $\left(25 \mu \mathrm{mol}\right.$ photons $\left.\mathrm{m}^{-2} \mathrm{~s}^{-1}\right)$ & $9.42 \pm 0.32 \mathrm{~b}$ & $96.50 \pm 2.49 \mathrm{~b}$ & $22.90 \pm 1.35 \mathrm{~b}$ & $1.58 \pm 0.12 \mathrm{~b}$ & $1.39 \pm 0.15 \mathrm{~b}$ \\
Red light $\left(30 \mu \mathrm{mol}\right.$ photons $\left.\mathrm{m}^{-2} \mathrm{~s}^{-1}\right)$ & $8.87 \pm 0.26 \mathrm{c}$ & $88.55 \pm 2.84 \mathrm{c}$ & $22.42 \pm 0.72 \mathrm{bc}$ & $1.32 \pm 0.11 \mathrm{c}$ & - \\
Green light $\left(28 \mu \mathrm{mol}\right.$ photons $\left.\mathrm{m}^{-2} \mathrm{~s}^{-1}\right)$ & $9.73 \pm 0.51 \mathrm{~b}$ & $100.62 \pm 2.63 \mathrm{~d}$ & $21.40 \pm 0.71 \mathrm{c}$ & $1.46 \pm 0.15 \mathrm{bc}$ & - \\
\hline
\end{tabular}



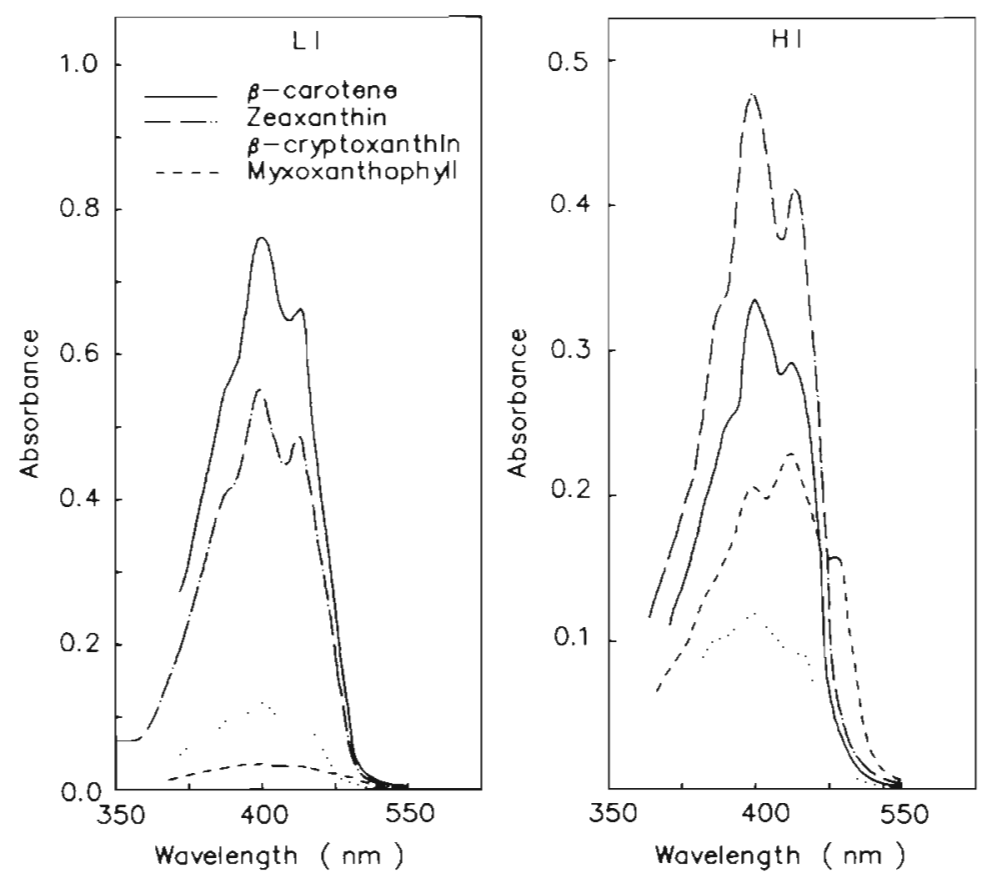

Fig. 1. Absorption spectra of the prevailing carotenoids from Spirulina subsalsa $3 \mathrm{~F}$ cultures grown under $15 \mu \mathrm{mol}$ photons $\mathrm{m}^{-2} \mathrm{~s}^{-1}$ (LI) and $100 \mu \mathrm{mol}$ photons $\mathrm{m}^{-2} \mathrm{~s}^{-1}$ (HI) of continuous PAR. Note that the absorbance scales are different.

acclimation (Fig, 2). In fact, at PFDs greater than $150 \mu \mathrm{mol}$ photons $\mathrm{m}^{-2} \mathrm{~s}^{-1}$ the photosynthetic activity of the HI cultures was always higher than that of LI cultures. The maximum photosynthetic activity $\left(\mathrm{P}_{\max }\right)$ in the former was more than $20 \%$ greater than in the latter. As expected, dark respiration was also greater in $\mathrm{HI}$ cultures $\left(79 \mu \mathrm{mol} \mathrm{O} \mathrm{mg}^{-1} \mathrm{chl} \mathrm{a} \mathrm{h}^{-1}\right.$ ) than in LI cultures $\left(39 \mu \mathrm{mol} \mathrm{O}_{2} \mathrm{mg}^{-1} \mathrm{chl} \mathrm{a} \mathrm{h}^{-1}\right)$. The greater photosynthetic activity observed at PFDs less than $150 \mu \mathrm{mol}$ photons $\mathrm{m}^{-2} \mathrm{~s}^{-1}$ in cultures acclimated to LI (Fig. 2) is explained by the great capacity of this strain to alter lightharvesting through a considerable increase of pigment cell content, especially CPE (Table 1).

\section{Effect of PFD on growth and cell composition}

Growth rate increased with the increase of PFD levels and was enhanced up to $100 \mu \mathrm{mol}$ photons $\mathrm{m}^{-2} \mathrm{~s}^{-1}$. Cultures growing at high irradiance showed a mean generation time of $27 \mathrm{~h}$, whereas it took $36 \mathrm{~h}$ in the cultures growing at $25 \mu \mathrm{mol}$ photons $\mathrm{m}^{-2} \mathrm{~s}^{-1}$. The biochemical composition of Spirulina subsalsa, expressed as \% of dry weight, changed from low to high growth irradiance, shifting from a prevalence of proteins $147.7 \%$ compared to $33.2 \%$ of carbo- hydrates) to a prevalence of carbohydrates (43.6\% compared to $36.8 \%$ of proteins). Lipids remained unchanged $(7.1 \%$ and $6.8 \%$ under low and high irradiance, respectively).

\section{Effect of spectral quality on photosynthetic activity}

The photosynthetic activities of Spirulina subsalsa cultures exposed to white, red and green light at similar PFDs were compared (Table 2). Similar values for photosynthetic activity were observed under white and green light, whereas under red light the value was about $20 \%$ lower.

\section{DISCUSSION AND CONCLUSIONS}

Spirulina subsalsa strain 3F efficiently regulated pigment content in response to PFD changes. It followed classical photoacclimation mechanisms of cyanobacteria, which are decreases in cell content of both chl a and PBPs, following a shift from lower to higher growth irradiance (Post 1986, Wyman \& Fay 1987. Millie et al. 1990, Falkowski \& LaRoche 1991). The pigment required to sustain the energy needs of cells at their division rate decreases (Van Liere \& Walsby 1982). The reduction in pigment content, accompanied by the decline of light-harvesting appa-

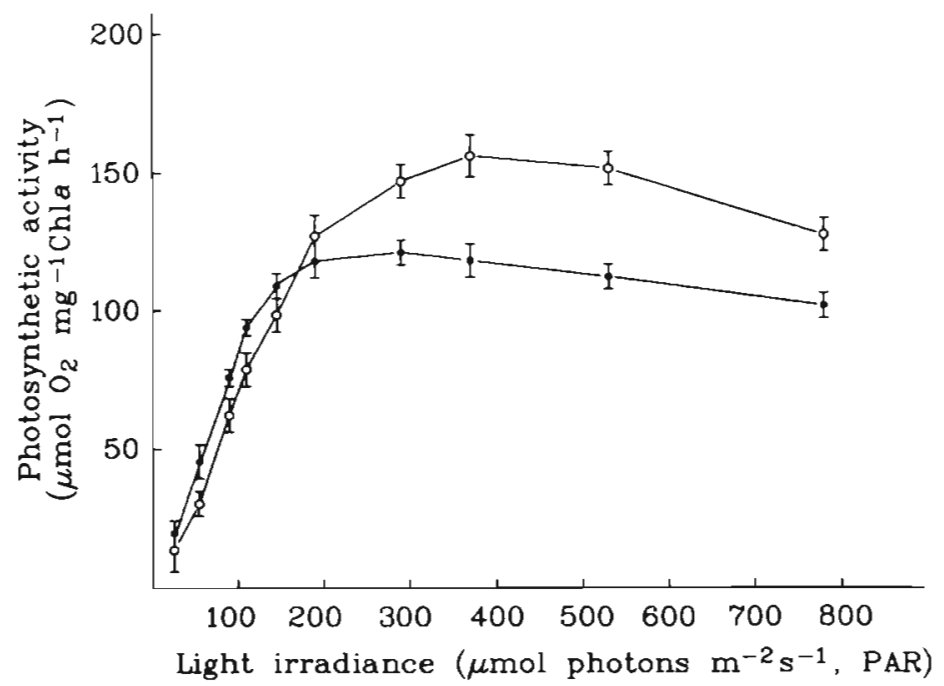

Fig. 2. Photosynthetic activity of Spirulina subsalsa 3F cultures acclimated at $15 \mu \mathrm{mol}$ photons $\mathrm{m}^{-2} \mathrm{~s}^{-1}(\bullet)$ and $100 \mu \mathrm{mol}$ photons $\mathrm{m}^{-2} \mathrm{~s}^{-1}$ (o) of continuous PAR. Values are means and error bars are \pm standard deviations $(n=4)$ 
Table 2. Effects of light spectral quality on photosynthetic activity of Spirulina subsalsa $3 \mathrm{~F}$ cultures. Data are means \pm standard deviation $(n=3)$. Variable means with the same letter are not significantly different $(p>0.05)$

\begin{tabular}{|c|c|}
\hline Light conditions & $\begin{array}{l}\text { Photosynthetic activity } \\
\left(\mu \mathrm{mol} \mathrm{O} \mathrm{O}_{2} \mathrm{mg}^{-1} \mathrm{chl} \mathrm{h} \mathrm{h}^{-1}\right)\end{array}$ \\
\hline $\begin{array}{l}\text { White light } \\
\left(250 \mu \mathrm{mol} \text { photons } \mathrm{m}^{-2} \mathrm{~s}^{-1}\right)\end{array}$ & $115.00 \pm 3.69 a$ \\
\hline $\begin{array}{l}\text { Red light } \\
\left(260 \mu \mathrm{mol} \text { photons } \mathrm{m}^{-2} \mathrm{~s}^{-1}\right)\end{array}$ & $93.02 \pm 3.17 \mathrm{~b}$ \\
\hline $\begin{array}{l}\text { Green light } \\
\left(240 \mu \mathrm{mol} \text { photons } \mathrm{m}^{-2} \mathrm{~s}^{-1}\right)\end{array}$ & $117.45 \pm 2.13 \mathrm{a}$ \\
\hline
\end{tabular}

ratus, leads to considerable conservation of energy that may be directed toward the biosynthesis of other cell constituents (Wyman \& Fay 1987). Indeed, in our experiments, when compared with cultures growing under low irradiance, those growing under high irradiance showed a reduction in cell contents of chl $a$ and even more of PBPs, accompanied by a decreased mean generation time ( 27 instead of $36 \mathrm{~h}$ ). The photosynthetic activities of $\mathrm{HI}$ grown cultures, measured at incident irradiances greater than $150 \mu \mathrm{mol}$ photons $\mathrm{m}^{-2}$ $\mathrm{s}^{-1}$, were also considerably higher than those of LI grown cultures. This may be a result of a lower incidence of the reciprocal shading of individual pigment molecules, which leads to a greater capacity of lightharvesting by each pigment molecule (Falkowski \& LaRoche 1991).

During the acclimation to high irradiance, the observed decrease in the cell chl a: carotenoids ratio, specifically affecting the synthesis of chlorophyll, suggests a photoprotective role for carotenoid pigments in Spirulina subsalsa 3F, as has been well documented in other cyanobacteria (Kellar \& Paerl 1980). Also, the increase in the relative abundance of myxoxanthophyll and zeaxanthin found in S. subsalsa 3F, similar to what Millie et al. (1990) observed in Oscillatoria agardhii, may be considered an adaptive response for protection against photooxidation. On the other hand, the greater carotenoid pigment content, observed in LI grown cultures of S. subsalsa 3F, seems to indicate also a considerable contribution of these Iipophilic pigments to light-harvesting, as already proposed for bloom-forming cyanobacteria (Paerl et al. 1983, Paerl 1984). In particular, the $\beta$-carotene increase in LI grown cultures, quite comparable with that observed both in O. agardhii (Millie et al. 1990) and in Spirulina platensis (Olaizola \& Duerr 1990), is in agreement with a light-harvesting or structural role of this pigment in the photosystem I (Olaizola \& Duerr 1990). Therefore, our results indicate that in the strain 3F carotenoids may serve as an accessory pigment and for photoprotection.
The ability of Spirulina subsalsa to increase the $\beta$ carotene cell content may be of ecological relevance in the eutrophic, sulphide-rich and scarcely transparent waters of Lake Faro, where the most penetrating component of the downwelling radiation is the low-wavelength blue and green light absorbed specifically by $\beta$-carotene and phycoerythrin (Skulberg 1978). The efficient utilization of low-wavelength light shown by this strain also resulted from the greater photosynthetic activities measured under green light in respect to red light of similar quantum flux.

Therefore, Spirulina subsalsa strain 3F appears to be well adapted to the environment where it lives with its specific equipment of antenna pigments, the prevalence of CPE, and the capability of extensive accumulation of this pigment under low irradiance. Despite the fact that it grows in a relatively narrow range of low irradiance, this organism shows a certain degree of photoacclimation to high PFD. This is due not only to pigment regulation, but also to its capability to dissipate a greater fraction of the light energy absorbed by CPE as autofluorescence (Tomaselli et al. 1993). The latter phenomenon, previously observed in a marine phycoerythrin-rich Synechococcus strain, is considered to be of strategical importance in preventing photoinhibition (Wyman et al. 1985).

The behavior of Spirulina subsalsa 3F in the photoacclimation response to high growth irradiance, together with the lack of chromatic adaptation, could be a good basis for the exploitation of this organism as a source of phycofluors.

Acknowledgements. Research supported by the National Research Council of Italy, Special Project RAISA, Sub-project 4, paper no. 1769. The authors are grateful to Dr M. Bindi of the Ce.S.I.A., Accademia dei Georgofili of Florence, for carryıng out the statistical data analyses, and M. D. Mannelli of the DISTAM at the University of Florence, for the drawings.

\section{LITERATURE CITED}

Anagnostidis K, Golubic S (1966) Über die Ökologıe einiger Spirulina-Arten. Nova Hedwigia 11:309-335

Bazzichelli G. Abdelahad N, Florenzano G, Tomaselli L (1978) Contributo alla conoscenza delle Terme di Saturnia (Toscana) Ann Bot 37:203-232

Bennett A, Bogorad L (1973) Complementary chromatic adaptation in a filamentous blue-green alga. J Cell Biol 58: $419-435$

Castenholz RW (1977) The effect of sulphide on the bluegreen algae of hot springs. II. Yellowstone National Park. Microb Ecol 3:79-105

Davies BH (1965) Analysis of carotenoid pigments. In: Goodwin TW (ed) Chemistry and biochemistry of plant pigments. Academic Press, New York, p 489-532

Falkowski PG, LaRoche J (1991) Acclimation to spectral irradiance in algae. J Phycol 27:8-14

Kellar PE, Paerl HW (1980) Physiological adaptations in 
response to environmental stress during an $\mathrm{N}_{2}$-fixing Anabaena bloom. Appl environ Microbiol 40:587-595

Millie DF, Ingram DA, Dionigi CP (1990) Pigment and photosynthetic responses of Oscillatoria agardhii (Cyanophyta) to photon flux density and spectral quality. J Phycol 26: $660-666$

Olaizola M, Duerr EO (1990) Effects of light intensity and quality on the growth rate and photosynthetic pigment content of Spirulina platensis. J appl Phycol 2:97-104

Paerl HW (1984) Cyanobacterial carotenoids: their roles in maintaining optimal photosynthetic production among aquatic bloom forming genera. Oecologia 61:143-149

Paerl HW, Tucker J, Bland PT (1983) Carotenoid enhancement and its role in maintaining blue-green algal (Microcystis aeruginosa) surface blooms. Limnol Oceanogr 28 : $847-857$

Paoletti C (1969) Indagini sui pigmenti carotenoidi di alcune Chlorophyceae unicellulari impiegate in coltura massiva. Ann Microbiol 19:121-130

Post A (1986) Transient state characteristics of adaptation to changes in light conditions for the cyanobacterium Oscillatoria agardhii. I. Pigmentation and photosynthesis. Arch Microbiol 145:353-357

Rippka R, Deruelles J, Waterbury JB, Herdman M, Stanier RY (1979) Generic assignments, strain histories and properties of pure cultures of cyanobacteria. J gen Microbiol 111 $1-61$

Skulberg OM (1978) Some observations on red-coloured species of Oscillatoria (Cyanophyceae) in nutrient-enriched lakes of southern Norway. Verh int Limnol 20:776-778
Strier L, Glazer A, Vernon T (1985) Fluorescent immunoassay employing a phycobiliprotein labeled ligand or receptor. US Patent 4:110-120

Tomaselli Feroci L, Balloni W (1976) Spirulina labyrinthiformis Gomont: prima segnalazione nelle Terme di Segesta (Sicilia). Gior Bot It 110:241-252

Tomaselli L, Margheri MC. Sacchi A (1990) Occurrence of red pigmented filamentous cyanobacteria (Lyngbya sp and Spirulina subsalsa) in deep water in Lake Faro (Italy), 20. In: 5th ICAA: Recent Advances in Algal Biotechnology, Jan 28 - Feb 2, Tiberias, Israel

Tomaselli L, Margheri MC, Materassi R (1993) Response of a red Spirulina subsalsa strain to changes in light intensity and spectral quality, 105. In: 6th ICAA: Algal Biotechnology, Progress in Biotechnology of Photoautotrophic Microorganisms, 6-11 Sept, Ceske Budejovice, Czech Republic

Tredici MR, Margheri MC, De Philippis R, Bocci F, Materassi $R$ (1988) Marine cyanobacteria as a potential source of biomass and chemicals. Int J Solar Energy 6:235-246

Van Liere L, Walsby AE (1982) Interactions of cyanobacteria with light. In: Carr NG, Whitton BA (eds) The biology of cyanobacteria. Blackwell Sci Publ, Oxford, p 9-45

Vonshak A, Cohen Z, Richmond A (1985) The feasibility of mass cultivation of Porphyridium. Biomass 8:13-25

Wyman M, Fay P (1987) Acclimation to natural light climate. In: Fay P, Van Baalen C (eds) The Cyanobacteria. Elsevier Sci Publ, Amsterdam, p 347-376

Wyman M, Gregory RPF, Carr NG (1985) A novel role for phycoerythrin in the marine cyanobacterium Synechococcus sp. DC2. Science 230:818-820 